\title{
Utilization and expenditure on long-acting insulin analogs among selected middle-income countries with high patient co-payment levels: Findings and implications for the future
}

\author{
Mainul Haque ${ }^{1}$ (D), Salequl Islam² (D), Abdullahi Rabiu Abubakar ${ }^{3}$ (D), Ibrahim Haruna Sani ${ }^{4}$ (D), Sylvia Opanga ${ }^{5}$, \\ Zubair Mahmood Kamal ${ }^{6}$ (D), Farhana Akter ${ }^{7}$ (D), Brian Godman $8,9,10^{*}$ (i) \\ ${ }^{1}$ Unit of Pharmacology, Faculty of Medicine and Defence Health, Universiti Pertahanan Nasional Malaysia National Defence University of Malaysia, Kuala \\ Lumpur, Malaysia. \\ ${ }^{2}$ Department of Microbiology, Jahangirnagar University, Dhaka, Bangladesh. \\ ${ }^{3}$ Department of Pharmacology and Therapeutics, Faculty of Pharmaceutical Sciences, Bayero University, Kano, Nigeria. \\ ${ }^{4}$ Unit of Pharmacology, College of Health Sciences, Yusuf Maitama Sule University YUM SUK, Kano, Nigeria. \\ ${ }^{5}$ Department of Pharmaceutics and Pharmacy Practice, School of Pharmacy, University of Nairobi, Nairobi, Kenya. \\ ${ }^{6}$ Department of Psychiatry, National Institute of Mental Health NIMH, Dhaka, Bangladesh. \\ ${ }^{7}$ Department of Endocrinology, Chittagong Medical College, Chattogram, Bangladesh. \\ ${ }^{8}$ Strathclyde Institute of Pharmacy and Biomedical Sciences, University of Strathclyde, Glasgow, UK. \\ ${ }^{9}$ Division of Public Health Pharmacy and Management, School of Pharmacy, Sefako Makgatho Health Sciences University, Pretoria, South Africa. \\ ${ }^{10}$ School of Pharmaceutical Sciences, Universiti Sains Malaysia, Gelugor, Malaysia.
}

\begin{tabular}{l}
\hline ARTICLE INFO \\
\hline Received on: $21 / 04 / 2021$ \\
Accepted on: $01 / 06 / 2021$ \\
Available online: $05 / 07 / 2021$
\end{tabular}

\section{Key words:}

Affordability, Bangladesh, diabetes, Kenya, long-acting insulin analogs, Nigeria.

\begin{abstract}
The number of patients with diabetes and associated complications is rising across countries including patients requiring insulin to control their diabetes. Hypoglycemia combined generally with poor control adds to the burden of diabetes. Long-acting insulin analogs were developed to reduce hypoglycemia, including nocturnal hypoglycemia, and enhance adherence, which can be a problem. These benefits have resulted in their increased use among high and highmiddle income countries, which is continuing. However, concerns in middle and lower-income countries as insulin analogs are considerably more expensive than standard insulins. Biosimilars can reduce their costs. Consequently, it is important to ascertain current usage and prices of analogs across middle-income countries with high patient co-payment levels to provide future direction. Overall, limited use of insulin glargine in Kenya, up to 3.6\% of total insulins in one leading hospital with prices up to 3.4 fold higher than standard insulins. Overall, limited use of insulin glargine among hospitals in Northern Nigeria and in pharmacies again due to high prices. Appreciably higher use of long-acting insulin analogs in Bangladesh enhanced by low cost biosimilars with increasing competition. Increased competition enhanced by local production can lower biosimilar costs enhancing future use of insulin glargine to the benefit of all diabetes patients requiring insulin.
\end{abstract}

${ }^{*}$ Corresponding Author

Brian Godman, Strathclyde Institute of Pharmacy and Biomedical Sciences, University of Strathclyde, Glasgow, UK; Division of Public Health Pharmacy and Management, School of Pharmacy, Sefako Makgatho Health Sciences University, Pretoria, South Africa; School of Pharmaceutical Sciences, Universiti Sains Malaysia, Gelugor, Malaysia. E-mail:Brian.Godman@strath.ac.uk

\section{INTRODUCTION}

There is an estimated 451-463 million people worldwide with diabetes mellitus (Chan et al., 2021; Liu et al., 2020), with current growth rates likely to continue (Chan et al., 2021; Lin et al., 2020). This includes sub-Saharan Africa where the prevalence of diabetes is likely to reach 34.2 million by 2040 , and rising up to 42-47 million patients across the whole of Africa by 2045 unless addressed (Godman et al., 2020a; Hamid et al., 2019; International Diabetes Feceration, 2019a). We are seeing 
similar high prevalence and growth rates of patients with diabetes among Asian countries including Bangladesh, India, Malaysia, and Pakistan (Afroz et al., 2019; India State-Level Disease Burden Initiative Diabetes C, 2018; International Diabetes Federation, 2019a; Rahim et al., 2020). Overall, low- and middle-income countries (LMICs) account for the vast majority of patients with diabetes world-wide (Chan et al., 2021; Lin et al., 2020), and this will continue.

These high and growing prevalence rates will have an appreciable impact on morbidity, mortality, and health related costs among LMICs (Chan et al., 2021; Lin et al., 2020; India State-Level Disease Burden Initiative Diabetes C, 2018; Bommer et al., 2018; Mutyambizi et al., 2018; Mapa-Tassou et al., 2019). This adds to the growing burden of non-communicable diseases (NCDs) across Asia and sub-Saharan Africa (Bigna and Noubiap, 2019; Gouda et al., 2019; Jakovljevic et al., 2015; Rijal et al., 2018). This is critical especially among LMICs where there are high patient co-payments, and family members becoming ill can have catastrophic consequences for families (Aregbeshola et al., 2018; Khan et al., 2017; Murphy et al., 2020; Rijal et al., 2018). The impact of diabetes on morbidity, mortality, and costs is exacerbated by associated microvascular and macrovascular complications. This includes blindness, non-traumatic lower-extremity amputations, chronic kidney disease as well as cardiovascular disease (Chan et al., 2021; Einarson et al., 2018; Gerstein 2015; International Diabetes Federation, 2019b; Rwegerera et al., 2018). Typically, poor control of diabetes and its complications as well as hypoglycemia contribute to this growing burden of diabetes (International Hypoglycaemia Study Group, 2019; Mbanya et al.,
2020; Pillay et al., 2016). As a result, estimated costs associated with the management of patients with diabetes world-wide were up to US $\$ 1.3$ trillion in 2015 , potentially rising to US\$2.1-US\$2.5 trillion by 2030 , equating to over $2 \%$ of Gross Domestic Product (Bommer et al., 2018; Mapa-Tassou, 2019).

Alongside this, there are growing concerns generally regarding the management of patients with diabetes among African countries, especially those with high co-payment levels (Godman et al., 2020a, 2020b; Opanga et al., 2021a). This includes patients requiring insulin, which incorporates a growing proportion of patients with Type 2 diabetes in LMICs (Haque et al., 2021a; Opanga et al., 2021 a; Venkataraman et al., 2020). Insulin has been in existence for almost 100 years to treat patients with diabetes (Fig. 1) (Barbetti and Taylor, 2019; Elliot et al., 2016). However, there are concerns on its availability among LMICs, especially among African countries, exacerbated by high costs with currently only three pharmaceutical companies dominating the global market in terms of overall utilization and value (Beran et al., 2019, 2021; Ewen et al., 2019). This is leading to a number of activities to try and address issues of access and availability among African and other LMICs including the ACCISS (Addressing the Challenge and Constraints of Insulin Sources and Supply) initiative (Beran et al., 2018, 2019; Lontchi-Yimagou et al., 2017; Shannon et al., 2019).

In Kenya, the costs of medicines to treat patients with diabetes and associated co-morbidities currently account for an average $52.4 \%$ of the total costs for those attending public healthcare facilities (Oyando et al., 2020). Such costs can have catastrophic consequences on families especially where insulin

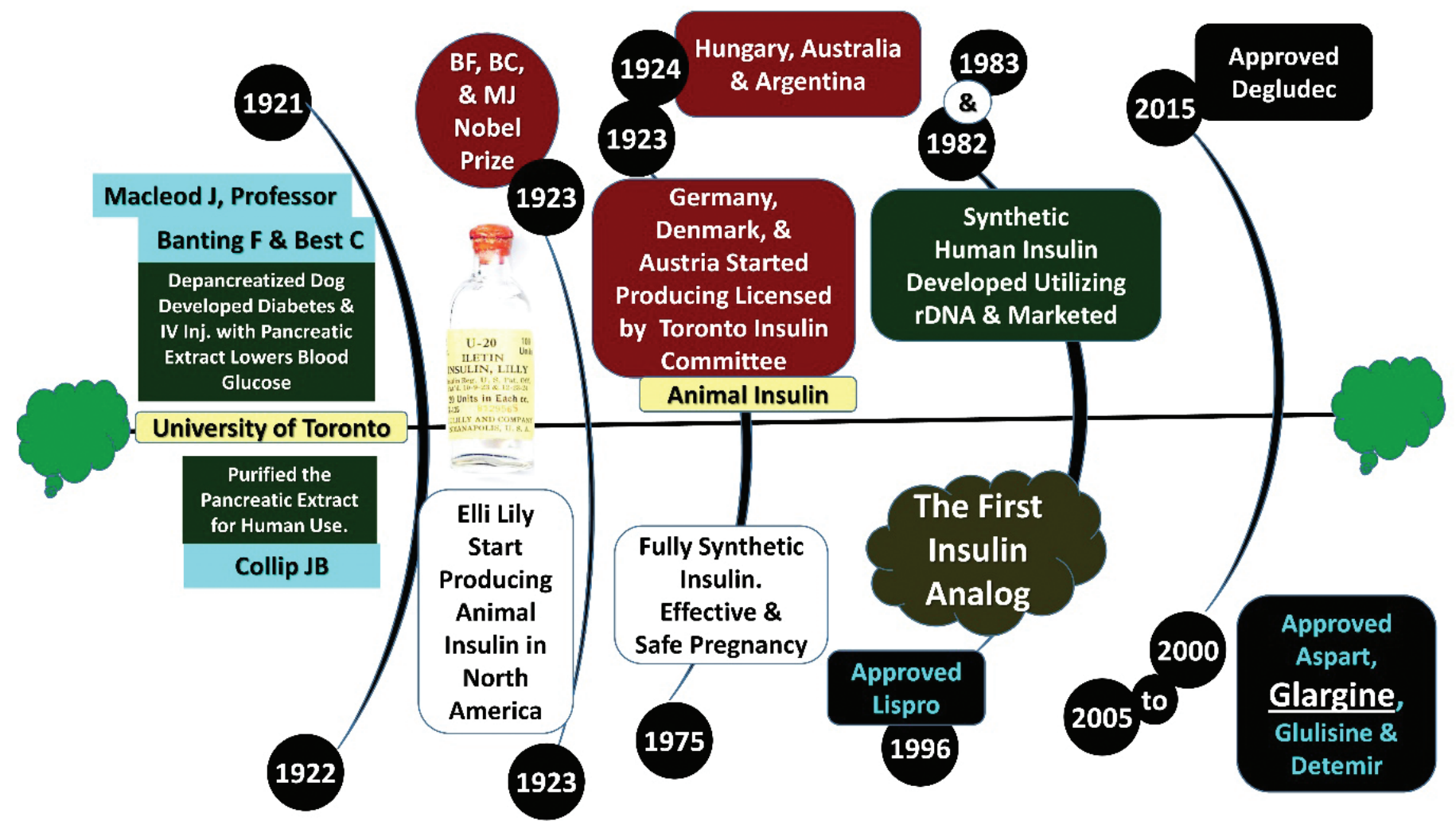

Figure 1. History of insulin. 
is needed. Concerns with access to pertinent medicines for patients with diabetes in Kenya, as well as misdiagnosed patients, have resulted in a number of projects in the country to address diagnostic and treatment concerns including the Base of Pyramid (BoP) project. The aim of the BoP project in Kenya is to improve the diagnosis of patients with diabetes as well as instigate a ceiling price for regular insulins such as insulin Mixtard $^{\circledR}$ at KSh 500-600 (US\$5) per 1000 IU among participating clinics and pharmacies to enhance the affordability of insulin, with this price equating up to a two-thirds price reduction (Shannon et al., 2019). This initiative builds on projects from other pharmaceutical companies in Kenya to help ensure that low cost medicines are available to treat patients with diabetes and their complications including hypertension (Mbui et al., 2017; Sandoz - A Novartis Division, 2015).

In Nigeria, the costs of medicines to treat patients with diabetes and its complications can be as high as $90 \%$ of total costs, much of which will be out-of-pocket (Fadare et al., 2015; Mutyambizi et al., 2018). As a result, discussing treatment costs is very important when physicians manage patients with NCDs in Nigeria to enhance the chances of patients purchasing and consuming prescribed medicines (Fadare et al., 2020). We are also seeing Novo Nordisk seeking to offer insulin free to children in Nigeria to again address concerns with access and affordability of insulins (Premium Times, 2020). Other donor and government activities across Africa to increase access to insulins include initiatives in Mozambique and Zambia. In these two countries, the International Insulin Foundation is working with the governments to enhance access to insulin (International Insulin Foundation) through alleviating issues of co-payments in community pharmacies. Alongside this, Biocon is looking to take part in a pan-African project entitled "Mission 10 cents" starting in Tanzania whereby certain insulins will be sold at less than 10 US cents per day (Ndilwa et al., 2020). Such initiatives are likely to grow given the increasing burden of diabetes in Africa (Godman et al., 2020a, 2020b).

We are also seeing concerns with the management of diabetes among Asian countries including Bangladesh, India, and Pakistan (India State-Level Disease Burden Initiative Diabetes Collaborators, 2018; International Diabetes Federation, 2019; Ewen et al., 2019), where the affordability of medicines including those to treat patients with diabetes can be a critical issue (Datta et al., 2020; Gillani et al., 2018; Saeed et al., 2020). Affordability of insulins is a key issue when it comes to long-acting insulin analogs as their appreciably higher price than standard insulins such as neutral protamine hagedorn (NPH) insulin has been a major concern in a number of LMICs (Almeida et al., 2018; Caires de Souza et al., 2014; Department of Health Republic of South Africa, 2020; Ewen et al., 2019). However, we are seeing growing use of long-acting insulin analogs in high and highmiddle income countries, as well as Asian countries such as Bangladesh, in view of their documented benefits in reducing rates of hypoglycemia, especially nocturnal hypoglycemia, as well as improving adherence to insulin administration through improved patient comfort (Chan et al., 2021; Ewen et al., 2019; Haque et al., 2021a; Laranjeira et al., 2018; Monami et al., 2009; PedersenBjergaard et al., 2014; Rys et al., 2015; Semlitsch et al., 2020; Tricco et al., 2021). It is, therefore, important to offer choices of different insulin preparations where possible given concerns with sub-optimal adherence to insulin therapy among patients (Davies et al., 2013; Peyrot et al., 2012; Spain et al., 2016). The patient benefits of long-acting insulin analogs are potentially further enhanced during religious festivals such as Ramadhan (Ahmed et al., 2017; Hassanein et al., 2017).

However, there can still be concerns with the potential health gain of long-acting insulin analogs versus NPH and other insulins (Hemmingsen et al., 2021). A number of studies though have shown that the higher acquisition costs of long-acting insulin analogs can potentially be offset by savings from averted costs elsewhere, which include the costs associated with hypoglycemia, other diabetes-associated complications, and potentially hospitalization (Alemayehu et al., 2018; Lee et al., 2020; Shafie et al., 2020). The availability of lower-cost biosimilars should help with issues of affordability as seen generally across countries as well as with long-acting insulin analogs as seen in Bangladesh (Haque et al., 2021a; Jensen et al., 2020; Moorkens et al., 2021).

The availability of low cost biosimilars should also be useful to African countries such as Kenya where despite long-acting insulin analogs being listed in the Kenyan Essential Medicine List (Ministry of Health Republic of Kenya, 2019), there is limited use to date due to issues of affordability (Opanga et al., 2021a). This is particularly important among African countries with high levels of co-payment given the pressures on families when members become ill especially with chronic long-term NCDs (Aregbeshola and Khan, 2018; Godman et al., 2020a, 2020b). There are also concerns with the additional costs of longacting insulin analogs compared to NPH and other similar insulins among LMICs including African countries such as Botswana, Namibia, and South Africa with their universal healthcare systems, which also limits the funding and prescribing of longacting within public clinics until procured prices appreciably fall (Department of Health Republic of South Africa, 2020; Godman et al., 2020b). However, we are unaware of the situation regarding long-acting insulin analogs including biosimilars in Nigeria with currently high co-payments within their healthcare system to provide future direction. This is important in Africa given the size of the population in Nigeria versus a number of African countries and concerns with issues of affordability and compliance with medicines for patients with NCD (Aregbeshola et al. 2018; Fadare et al., 2020).

Consequently, we wanted to assess the current situation with respect to long-acting insulin analogs in Nigeria including biosimilars and potential strategies to enhance their use, especially biosimilars, where continued concerns with their value. This builds on the current situation in other LMICs with high patient co-payment levels including Bangladesh and Kenya (Haque et al., 2021b; Opanga et al., 2021a; Sefah et al., 2021), and could build on discussions across Africa to stimulate local production of medicines following the recent coronavirus disease (COVID-19) pandemic as well as prequalification initiatives by the World Health Organization (WHO) to stimulate competition to lower insulin prices (Ekeigwe et al., 2019; Ogunleye et al., 2020; WHO, 2019). The findings can be used to provide guidance to the authorities in Nigeria and wider to enhance potential choices including longacting insulin analogs where there are still concerns. 


\section{MATERIALS AND METHODS}

We adopted a mixed approach depending on the current situation within the chosen countries. This builds on similar research activities among other LMICs as well as previous research projects surrounding the utilization and expenditure of medicines to treat patients with COVID-19 among African and Asian countries (Godman et al., 2020c; Haque et al., 2021a, 2021b, 2021c; Kibuule et al., 2021; Opanga et al., 2021a; Sefah et al., 2021).

In the case of Nigeria, this involved approaching hospitals as well as community pharmacists to ascertain current utilization and pricing levels for long-acting insulin analogs principally concentrating on insulin glargine as this was the only biosimilar available. We concentrated on Kano in Northern Nigeria for this initial research as the Kano metropolis is the commercial hub in Northern Nigeria and the second largest city in Nigeria with an estimated population of just under 4 million people. In addition, we have successfully undertaken similar projects in this metropolis (Haque et al., 2021b; Sefah et al., 2021).

The research was divided into two parts covering both hospitals and community pharmacies. We chose community pharmacies since patients in Nigeria typically purchase their medicines directly from such stores especially if there are medicine shortages within public hospitals, which can be frequent in Nigeria (Fadare et al., 2020; Haque et al., 2021b). The hospitals as well as community pharmacies and drug stores in Nigeria were purposely selected to provide relevant information to guide future discussions. There were no sample size calculations as our aim for this initial study was to gain greater understanding of the current situation since we were unaware of any previous research in this area in Nigeria. This is similar to our previous study in Nigeria as well as other African countries regarding activities concerning the purchasing of medicines during the initial months following the recent COVID-19 pandemic (Haque et al., 2021b; Kibuule et al., 2021; Sefah et al., 2021).

Three hospitals in the Northern part of Nigeria were approached to assess total annual utilization of long-acting insulin analogs (insulin glargine) versus short, medium, and longer-acting human insulins. These included Aminu Kano Teaching Hospital, Murtala Muhammad Specialist Hospital, and Muhammadu Abdullahi Wase Specialist Hospital. In this study, utilization data was depicted in packs to compare utilization across the studied years. Alongside this, collecting data on utilization (in terms of packs) and prices (initially in local currency) of long-acting insulin analogs from 11 community pharmacies and drug stores in Kano, Northern Nigeria, between 2019 and 2020. This is similar to the approach in Bangladesh as well as previously in Nigeria immediately following the COVID-19 pandemic (Haque et al., 2021a, 2021b). Defined daily doses (DDDs) were used in Kenya (Opanga et al., 2021a). Utilization patterns in Nigeria will subsequently be compared to utilization and expenditure patterns on the different insulins, including insulin glargine, in Bangladesh and Kenya. This will be supplemented by the considerable knowledge of the senior level co-authors working across multiple African and Asian countries to provide future direction similar to other studies (Godman et al., 2020a, 2020c, 2020d; Haque et al., 2021c; Ogunleye et al., 2020; Sefah et al., 2021).
The findings in Bangladesh and Kenya have already been published (Haque et al., 2021a; Opanga et al., 2021a). These included the situation in both hospitals and community pharmacies in Bangladesh among both private and public hospitals (Haque et al., 2021 a). Community pharmacies were approached in Bangladesh since there is limited dispensing of medicines among private hospitals in Bangladesh and only standard insulins such as NPH insulins are provided free among public hospitals while stocks last (Haque et al., 2021a).

Community pharmacists were not approached in Kenya, unlike studies assessing the impact of COVID-19 on prescribing patterns for pertinent medicines, since if there was limited prescribing of long-acting insulin analogs among referral hospitals there would be limited or no dispensing in the community (Opanga et al., 2021a, 2021b). The two hospitals chosen in Kenya for this initial study were Kenyatta National Hospital (KNH) and Embu County Referral Hospital (ECRH). Both KNH and ECRH are the largest public referral hospitals in their region, with $\mathrm{KNH}$ also offering quality specialized healthcare to patients across Kenya and wider (Kivoto et al., 2018; Opanga et al., 2021a). ECRH is located in Central Kenya where there is a high prevalence of diabetes mellitus (Opanga et al., 2021a).

We did not seek ethical approval as we were not dealing with patients, in line with national legislation and institutional guidelines (Godman et al., 2020c; Haque et al., 2021b, 2021c; Sefah et al., 2021). Besides, community pharmacists and drug store owners taking part in this study freely provided the requested information after being given the opportunity to refuse to participate if they wished. This is in line with previous studies undertaken by the co-authors in related areas. This includes analysis of policies to enhance the rational use of medicines and biosimilars, as well as pricing policies and issues surrounding biosimilars and generics, all of which involved direct contact with key personnel (Godman et al., 2019, 2020a, 2020b, 2020d, 2020e; Miljković et al., 2020; Moon et al., 2014; Moorkens et al., 2021).

\section{RESULTS}

We will first discuss changes in the utilization of longacting insulin analogs, principally insulin glargine, among the hospitals in Bangladesh, Kenya, and Nigeria before discussing the situation seen among community pharmacies in Bangladesh and Nigeria.

In view of the situation seen in KNH and ECRH (Table 1), it is likely there will be limited utilization of insulin glargine generally throughout Kenya, with prices of insulin glargine 3.4 fold higher on a daily basis compared with soluble insulin and insulin Mixtard $^{\circledR}$ and continuing issues of affordability (Ewen et al., 2019; Opanga et al., 2021a; Shannon et al., 2019). Prices of insulin glargine will need to fall considerably in Kenya to enhance its utilization even among regional referral hospitals despite longacting insulins being included in the Kenyan EML (Ministry of Health Republic of Kenya., 2019; Opanga et al., 2021a), which is similar to other African countries including Botswana Nigeria and South Africa (Department of Health Republic of South Africa, 2020; Godman et al., 2020b; Opanga et al., 2021a).

Overall, insulin analogs, including long-acting insulin analogs, were increasingly dispensed among community pharmacies and drug stores in Bangladesh in 2020 versus 2019, 
Table 1. Utilization and pricing patterns for different insulin preparations among hospitals in Bangladesh, Kenya, and Nigeria.

\begin{tabular}{|c|c|}
\hline Country & Findings \\
\hline \multirow[t]{6}{*}{ Bangladesh } & $\begin{array}{l}\text { - The prescribing of long-acting insulin analogs among both private and public hospitals varied according to the hospital type as well as } \\
\text { the prescribing physician }\end{array}$ \\
\hline & $\begin{array}{l}\text { - Typically, long-acting insulin analogs were prescribed more by endocrinologists than other physicians. However, the trend among all } \\
\text { physicians is to increase the prescribing of long-acting insulin analogs in view of their perceived benefits }\end{array}$ \\
\hline & - Among the participating hospitals: \\
\hline & (a) Prescribing of long-acting insulin analogs varied from as low as $10 \%-15 \%$ of all insulins prescribed up to a maximum of $45 \%-50 \%$ \\
\hline & (b) Prescribing of insulin glargine versus other long-acting insulin analogs varied from as low as $20 \%-30 \%$ up to $80 \%-90 \%$ of prescriptions \\
\hline & $\begin{array}{l}\text { (c) In the case of insulin glargine, prescribing of biosimilars ranged from } 30 \%-40 \% \text { of all insulin glargine up to a maximum of } 98 \% \text { with } \\
\text { growing prescribing of biosimilars in recent years }\end{array}$ \\
\hline \multirow[t]{3}{*}{ Kenya } & $\begin{array}{l}\text { - There was generally limited prescribing of long-acting insulin analogs (glargine originator) among the two participating hospitals in } \\
\text { Kenya in recent years }\end{array}$ \\
\hline & $\begin{array}{l}\text { - In KNH, this was only } 0.5 \% \text { of total insulins dispensed in } 2015 \text { reaching up to } 3.4 \%-3.6 \% \text { of total insulin utilization in } 2019 \text { and } 2020 \text {. } \\
\text { The impact on expenditure was greater-up to } 8 \% \text { of total insulin costs }\end{array}$ \\
\hline & $\begin{array}{l}\text { - In ECRH where Insulin Mixtard }{ }^{\circledR} \text { was the principal insulin dispensed, with usage rising from } 2061 \text { packs in } 2015 \text { to } 5,627 \text { packs in } 2018 \\
\text { before falling to } 4,742 \text { packs in } 2019 \text {, with similar utilization up to June } 2020 \text {. There was no prescribing of any long-acting insulin analog }\end{array}$ \\
\hline \multirow[t]{4}{*}{ Nigeria } & $\begin{array}{l}\text { - In } 2019 \text {, dispensing of long-acting insulin glargine was limited versus standard insulins such as NPH insulin, and varied among the three } \\
\text { chosen hospitals. }\end{array}$ \\
\hline & $\begin{array}{l}\text { - Overall, utilization in } 2019 \text { ranged from } 50 \text { to } 100 \text { packs per year of } 5 \times 3 \mathrm{ml} 100 \mathrm{IU} / \mathrm{ml} \text { insulin glargine, with prices per pack ranging } \\
\text { from N3600 (US\$9.47) to N4300 (\$11.42) }\end{array}$ \\
\hline & - There were similar utilization patterns among the three chosen hospitals in the first half of 2020 \\
\hline & $\begin{array}{l}\text { - There were marginal increases in prices on long-acting insulin glargine (originator) in recent years, with prices ranging from N4000 } \\
\text { (US } \$ 10.53 \text { ), up from N3600, to N4500 (US } \$ 11.84 \text { ) in } 2020 \text { versus } 2019\end{array}$ \\
\hline
\end{tabular}

NB: KNH = Kenyatta National Hospital; ECRH = Embu County Referral Hospital.

Adapted from (Haque et al., 2021a; Opanga et al., 2021a).

accounting for over $50 \%$ of dispensed insulins among $46 \%$ of the 76 community pharmacies and drug stores surveyed in 2020 (Haque et al., 2021a). This was increasingly biosimilar insulin glargine, accounting for over $50 \%$ of insulin glargine dispensed in 54\% among 79 surveyed pharmacies and stores in 2020, with this trend continuing (Haque et al., 2021a). Biosimilars also accounted for just under $90 \%$ of dispensed insulin glargine in a further 15 surveyed community pharmacies in Bangladesh. The high rates of usage of insulin glargine biosimilars in Bangladesh in recent years was helped by price reductions of $50 \%$ or more for the biosimilars versus the originator, with currently no change in prices between 2019 and 2020 in the vast majority of pharmacies surveyed (Haque et al., 2021a). This contrasts with the low rates of biosimilar use in Nigeria (Table 2), reflecting general concerns with the quality of non-originator medicines in Nigeria (Fadare et al., 2016) as well as limited price differences in reality between originators and biosimilars, e.g., currently only a $4 \%$ difference between the biosimilar and the cheapest originator among the surveyed pharmacies.

Box 1 describes suggested activities that can be undertaken among LMICs with high co-payment levels to drive down costs of long-acting insulin biosimilars to improve patient access and choices building on the situation in Bangladesh.

\section{DISCUSSION}

We believe this is the first study to compare utilization and expenditure patterns for different insulin preparations, including long-acting insulin analogs, and their rationale, among middle-income countries with high patient co-payment levels. This is important compared with similar countries offering universal healthcare, whose goal is to maximize the health gain of their population within available resources. In this situation, health authorities are typically more active guiding physician prescribing to enhance the quality and efficiency of prescribing (Godman, 2021a; Godman et al., 2014a, 2014b; Meyer et al., 2017; Moon et al., 2014). This compares with situations where prescribing can be influenced by other factors including current incentives in the system enhancing inappropriate prescribing such as excessive use of injections, pharmaceutical companies encouraging the preferential prescribing of premium priced patented medicines versus considerably less expensive multiple sourced medicines without compromising care in the absence of multiple demand-side measures as well as patient pressure enhancing the prescribing and dispensing of antibiotics for essentially viral infections (Godman et al., 2010; 2014b; 2020d; Mao et al., 2015; Soleymani et al., 2019; Zeng et al., 2015). Having said this, we are seeing sub-Saharan African countries such as Kenya looking to make sure appropriate facilities, medicines, and personnel, are in place to improve the management of their population with diabetes (Opanga et al., 2021a). We are also seeing sub-Saharan African countries such as Namibia seek to establish pertinent quality indicators to improve the management of patients in ambulatory care especially those with NCDs including diabetes (Niaz et al., 2019). 
Table 2. Dispensing patterns for long-acting insulin analogs among community pharmacies in Bangladesh and Nigeria.

\begin{tabular}{|c|c|}
\hline Country & indings \\
\hline Bangladesh & $\begin{array}{l}\text { - Insulin analogs, including long-acting insulin analogs, were increasingly dispensed among the } 167 \text { community pharmacies and drug stores } \\
\text { surveyed in Bangladesh in } 2020 \text { versus } 2019 \text { divided into four groups } \\
\text { - Overall, insulin analogs were the principal insulin dispensed in over } 40 \% \text { of community pharmacies surveyed in one group in } 2020 \text {, and this } \\
\text { was increasingly the long-acting insulin analogs } \\
\text { - Biosimilars were the principal insulin glargine dispensed in over } 50 \% \text { of this group pharmacies surveyed, reaching over } 80 \% \text { in } 13 \% \text { of those } \\
\text { pharmacies surveyed } \\
\text { - The biosimilars were the principal preparations of insulin glargine dispensed in a further set of } 15 \text { pharmacies accounting for just under } 90 \% \\
\text { of all insulin glargine dispensed ( } 2019 \text { and } 2020 \text { ). There was a } 16.7 \% \text { increase in the number of insulin glargine packs dispensed in these } 15 \\
\text { pharmacies between } 2019 \text { and } 2020 \\
\text { - Prices for a number of the biosimilar insulin glargine preparations were over } 50 \% \text { below originator prices among pharmacies surveyed } \\
\text { - The considerable variation in dispensing patterns seen for the various insulin glargine preparations depended on a number of issues including } \\
\text { affordability and trust }\end{array}$ \\
\hline Nigeria & $\begin{array}{l}\text { - Among the } 11 \text { community pharmacies surveyed, the average number of packs of insulin glargine } 100 \mathrm{IU} / \mathrm{ml} \text { dispensed in } 2019 \text { ranged from } 35 \\
\text { to } 110 \text {, with an average of } 75 \text { packs } \\
\text { - There was a similar pattern in the first half of } 2020 \\
\text { - Biosimilar Glaritus }{ }^{\mathbb{8}} \text { only accounted for a small proportion of insulin glargine dispensed at under } 10 \% \text { in } 2019 \text { with similar low rates in } 2020\end{array}$ \\
\hline
\end{tabular}

Adapted from (Haque et al., 2021a).

Box 1. Activities that can be undertaken by Governments and others to improve availability and use of long-acting insulin analog biosimilars.

- Increased competition among biosimilar manufacturers can potentially lower the prices of biosimilars as seen in Bangladesh and in other situations in other countries (Beran et al., 2021; Haque et al., 2021a; Moorkens et al., 2021). Potential ways to achieve this include:

(a) Governments and procurement agencies building on the WHO prequalification initiative to enhance imports of biosimilars from other LMICs to reduce the monopoly on current insulin manufacturers (Beran et al., 2019, 2021; WHO, 2019).

(b) Governments working with manufacturers and others to make good quality long-acting insulin analogs available at lower prices, building on initiatives among a number of countries in Africa (Dehayem et al., 2016; Lontchi-Yimagou et al., 2017; Premium Times, 2020; Sandoz - A Novartis Division, 2015; Schäfermann et al., 2020; Shannon et al., 2019). Alongside this, governments looking to enhance local/regional production of biosimilars as seen in, e.g., Malaysia (Biocon, 2021; Singh, 2019).

- Alongside this, for instance, Pan-African consortia, with the help of WHO Africa and others, should seek to ensure where possible consistency in prices for biosimilar insulin glargine across Africa to reduce issues of parallel exportation and other concerns. Alongside this, Governments should review issues such as mark-ups of insulins to wholesalers and pharmacies to enhance their affordability where there are high co-payments. This especially as additional costs have ranged up to $565.8 \%$ for insulins among LMICs (Ball et al., 2019)

- Activities generally to enhance the utilization of lower cost biosimilar long-acting insulins where approved and funded include:

(a) Ministries of health and/or physicians groups enhancing local knowledge of the potential patient benefits with long-acting insulin analogs through studies as well as ensure the routine availability of biosimilar long-acting insulin analogs among all public health facilities especially hospitals/clinics reduce co-pays if patients have to pay for the insulin themselves in community pharmacies.

(b) This potentially involves Key personnel within Ministries of Health and Physician/Pharmacy Groups working together to collate ongoing clinical evidence to support the continued use and funding of long-acting insulin analogs.

- Physicians and pharmacists (as well as nurse practitioners in primary healthcare clinics) should work with patients to ensure they are familiar with the different pens/devices between different insulin glargine preparations if this is the case; however, reduced with national procurement practices.

- Physician and Pharmacy Groups should look to monitor HbAlc and hypoglycemia rates in patients prescribed long-acting insulin analogs to see if reduced rates of hypoglycemia/improved control are seen in practice, and subsequently broadcast any findings. Concurrent with this, key stakeholder groups should work with Governments and others to seek ways to enhance the routine availability of strips to improve home monitoring of blood glucose levels where there are continued concerns to improve patient care.

With the growing prevalence of patients with diabetes requiring insulin, it is increasingly important that patients have a full range of different varieties of insulins available to improve their control of diabetes, reduce hypoglycemia, including nocturnal hypoglycemia, as well as generally improve adherence to prescribed insulins given current concerns (Opanga et al., 2021a; Spain et al., 2016). This increasingly means routine access to long-acting insulin analogs at affordable prices. Increased availability of lower cost biosimilars can help achieve this as seen in Bangladesh versus
Kenya and Nigeria (Tables 1 and 2). Regions and countries can instigate a number of measures to engineer lower price for biosimilar insulin glargine to enhance their affordability and use (Box 1). This includes building on the WHO prequalification initiative, with increased competition likely to drive down the price of longacting insulin analogs especially given the low production costs for insulin glargine (Gotham et al., 2018; WHO, 2019). We have seen increased competition drive down the price of biosimilars in other markets providing examples (Davio, 2018; Godman, 2021b; 
ensen et al., 2020; Matusewicz et al., 2015; Moorkens et al., 2021). Alongside encouraging increased local production of biosimilar insulin glargine similar to initiatives in Malaysia through Biocon or other companies (Singh et al., 2019), and building on current agreements include Aspen Pharmaceuticals producing vaccines for COVID-19 for South Africa and wider (Kew, 2021). This should help bring down prices and builds on suggestions put forward by the East African Secretariat to stimulate the production of medicines in Africa to help contain costs and reduce future shortages (EAC Secretariat, 2020; Ogunleye et al., 2020).

Once there is increased availability of low cost longacting insulin analog biosimilars, key stakeholder groups, including physician and pharmacy groups as well as patient organizations, will be necessary to educate physicians and patients regarding similar safety and effectiveness between originator and biosimilars if this is seen as a potential problem (Aladul et al., 2018; Blevins et al., 2020; Hadjiyianni et al., 2016; Lamb and Syed, 2018). However, this does not appear to be a problem in Bangladesh with increasing use of biosimilar insulin glargine (Haque et al., 2021a). We have also seen high use of biosimilar insulin glargine among some ambulatory care groups in the United Kingdom but not all due to concerns (Agirrezabal et al., 2020; Aladul et al., 2018). Subsequently, routinely assess patients and medicine use during follow-up visits to ambulatory care clinics, including monitoring $\mathrm{HbAlc}$ levels and blood pressure, as well as the prescribing of medicines including statins given current concerns in LMICs with growing rates of complications among patients with diabetes (Chang et al., 2019; Madela et al., 2020; Mwita et al., 2019). The findings will enhance the knowledge base of the use of long-acting insulin analogs, including biosimilars, among LMICs providing future direction.

We are aware of a number of limitations with our study. These include the fact that we only included a small number of hospitals and pharmacists in Nigeria, and only from one region in Nigeria. However, we have documented the rationale for our approach and believe our findings to date add to the knowledge base of the current prescribing of long-acting insulin analogs including biosimilars in Nigeria. We also only approached a limited number of hospitals in Bangladesh and Kenya, and did not approach pharmacies in Kenya for the reasons given. We also typically documented prescribing patterns and packages dispensed rather than DDDs in Bangladesh and Nigeria for the reasons given. However, despite these limitations we believe our findings are robust enabling us to make comprehensive recommendations regarding future activities among African and Asian countries to increase availability and prescribing of long-acting insulin analogs.

\section{CONCLUSION}

In conclusion, it is encouraging to see growth in the prescribing and dispensing of long-acting insulin analogs, especially insulin glargine biosimilars, in Bangladesh enabling patients to benefit from their availability. The high prices of longacting insulin analogs, including insulin glargine, compared with standard insulins, including pre-mixed insulins, in Kenya and Nigeria need to be urgently addressed to enhance their funding and use. This will include increased availability of lower cost biosimilars, potentially enhanced by prequalification, local production initiatives as well as other activities.

\section{CONFLICT OF INTEREST}

The authors declare they have no competing interests.

\section{AUTHOR CONTRIBUTIONS}

All authors made substantial contributions to conception and design, acquisition of data, or analysis and interpretation of data; took part in drafting the article or revising it critically for important intellectual content; agreed to submit to the current journal; gave final approval of the version to be published; and agree to be accountable for all aspects of the work. All the authors are eligible to be an author as per the international committee of medical journal editors (ICMJE) requirements/guidelines.

\section{FUNDING}

This analysis was commissioned and paid for by the World Health Organization. The authors are totally responsible for the views expressed in this paper and they do not necessarily represent the decisions, policy or views of the World Health Organization.

\section{REFERENCES}

,Afroz A, Zhang W, Wei Loh AJ, Jie Lee DX, Billah B. Macro- and micro-vascular complications and their determinants among people with type 2 diabetes in Bangladesh. Diabetes Metab Syndr, 2019; 13(5):2939-46.

Agirrezabal I, Sánchez-Iriso E, Mandar K, Cabasés JM. Realworld budget impact of the adoption of insulin glargine biosimilars in primary care in England (2015-2018). Diabetes Care, 2020; 43(8): 1767-73.

Ahmed MH, Husain NE, Elmadhoun WM, Noor SK, Khalil AA, Almobarak AO. Diabetes and Ramadan: a concise and practical update. J Fam Med Prim Care, 2017; 6(1):11-8.

Aladul MI, Fitzpatrick RW, Chapman SR. Healthcare professionals' perceptions and perspectives on biosimilar medicines and the barriers and facilitators to their prescribing in UK: a qualitative study. BMJ Open, 2018; 8(11):e023603.

Alemayehu B, Speiser J, Bloudek L, Sarnes E. Costs associated with long-acting insulin analogues in patients with diabetes. Am J Manag Care, 2018; 24(8 Spec No.):Sp265-72

Almeida P, Silva TBC, de Assis Acurcio F, Guerra Junior AA, Araujo VE, Diniz LM, Godman B, Almeida AM, Alvares J. Quality of life of patients with type 1 diabetes mellitus using insulin analog glargine compared with NPH insulin: a systematic review and policy implications. Patient, 2018; 11(4):377-89.

Aregbeshola BS, Khan SM. Out-of-pocket payments, catastrophic health expenditure and poverty among households in Nigeria 2010. Int J Health Policy Manag, 2018; 7(9):798-806.

Ball D, Ewen M, Laing R, Beran D. Insulin price components: case studies in six low/middle-income countries. BMJ Global Health, 2019, 4(5):e001705.

Barbetti F, Taylor SI. Insulin: still a miracle after all these years. J Clin Invest, 2019; 129(8):3045-7.

Beran D, Hirsch IB, Yudkin JS. Why are we failing to address the issue of access to insulin? A national and plobal Perspective. Diabetes Care, 2018; 41(6):1125-31.

Beran D, Laing RO, Kaplan W, Knox R, Sharma A, Wirtz VJ, Frye J, Ewen M. A perspective on global access to insulin: a descriptive study of the market, trade flows and prices. Diabet Med, 2019; 36(6):726-33.

Beran D, Lazo-Porras M, Mba CM, Mbanya JC. A global perspective on the issue of access to insulin. Diabetologia, 2021a; 64(5):954-62.

Bigna JJ, Noubiap JJ. The rising burden of non-communicable diseases in sub-Saharan Africa. Lancet Glob Health, 2019; 7(10):e1295-6.

Biocon. Biosimilars - Insulins. 2021. Available via https://www. biocon.com/products/biosimilars/ 
Blevins TC, Barve A, Raiter Y, Aubonnet P, Athalye S, Sun B, Muniz R. Efficacy and safety of MYL-1501D versus insulin glargine in people with type 1 diabetes mellitus: results of the INSTRIDE 3 phase 3 switch study. Diabetes Obes Metab 2020; 22(3):365-72.

Bommer C, Sagalova V, Heesemann E, Manne-Goehler J, Atun R, Bärnighausen T, Davies J, Vollmer S. Global economic burden of diabetes in adults: projections from 2015 to 2030. Diabetes Care, 2018; 41(5):963-70.

Caires de Souza AL, de Assis Acurcio F, Guerra Junior AA, Rezende Macedo do Nascimento RC, Godman B, Diniz LM. Insulin glargine in a Brazilian state: should the government disinvest? An assessment based on a systematic review. Appl Health Econ Health Policy, 2014; 12(1):19-32.

Chan JCN, Lim LL, Wareham NJ, Shaw JE, Orchard TJ, Zhang P, Lau ESH, Eliasson B, Kong APS, Ezzati M, Aguilar-Salinas CA, McGill M, Levitt NS, Ning G, So WY, Adams J, Bracco P, Forouhi NG, Gregory GA, Guo J, Hua X, Klatman EL, Magliano DJ, Ng BP, Ogilvie D, Panter J, Pavkov M, Shao H, Unwin N, White M, Wou C, Ma RCW, Schmidt MI, Ramachandran A, Seino Y, Bennett PH, Oldenburg B, Gagliardino JJ, Luk AOY, Clarke PM, Ogle GD, Davies MJ, Holman RR, Gregg EW. The Lancet Commission on diabetes: using data to transform diabetes care and patient lives. Lancet, 2021; 396(10267):2019-82.

Chang H, Hawley NL, Kalyesubula R, Siddharthan T, Checkley W, KnaufF, Rabin TL. Challenges to hypertension and diabetes management in rural Uganda: a qualitative study with patients, village health team members, and health care professionals. Int J Equity Health, 2019; 18(1):38.

Datta BK, Husain MJ, Fatehin S. The crowding out effect of outof-pocket medication expenses of two major non-communicable diseases in Pakistan. Int Health, 2020; 12(1):50-9.

Davies MJ, Gagliardino JJ, Gray LJ, Khunti K, Mohan V, Hughes R. Real-world factors affecting adherence to insulin therapy in patients with type 1 or type 2 diabetes mellitus: a systematic review. Diabet Med, 2013; 30(5):512-24.

Davio K. After biosimilar deals, UK spending on adalimumab will drop by $75 \%$, 2018. Available via https://www.centerforbiosimilars $\mathrm{com} /$ news/after-biosimilar-deals-uk-spending-on-adalimumab-will-dropby- 75

Dehayem MY, Takogue R, Choukem SP, Donfack OT, Katte JC, Sap S, Sobngwi E, Mbanya JC. Impact of a pioneer diabetes camp experience on glycemic control among children and adolescents living with type 1 diabetes in sub-Saharan Africa. BMC Endocr Disord, 2016; 16:5.

Department of Health Republic of South Africa. National Essential Medicines List Committee (NEMLC) - tertiary and quarternary level essential medicines list reviewed items,. 2020. Available via http:// www.kznhealth.gov.za/pharmacy/Tertiary-quaternary-level-essentialmedicine-recommendations_January2020.pdf.

EAC Secretariat. East African community COVID-19 response plan. 2020. Available via: https://www.eac.int/coronavirus

Einarson TR, Acs A, Ludwig C, Panton UH. Prevalence of cardiovascular disease in type 2 diabetes: a systematic literature review of scientific evidence from across the world in 2007-2017. Cardiovasc Diabetol, 2018; 17(1):83.

Ekeigwe AA. Drug manufacturing and access to medicines: the West African story. A literature review of challenges and proposed remediation. AAPS Open, 2019; 5:3; doi:10.1186/s41120-019-0032-x

Elliot J, Besançon S, Sachs J. Almost 100 years after it was discovered, let's make access to insulin a reality in Africa!,. 2016. Available via https://ideas4development.org/en/almost-100-years-after-it-wasdiscovered-lets-make-access-to-insulin-a-reality-in-africa/.

Ewen M, Joosse HJ, Beran D, Laing R. Insulin prices, availability and affordability in 13 low-income and middle-income countries. BMJ Glob Health, 2019; 4(3):e001410.

Fadare J, Olamoyegun M, Gbadegesin BA. Medication adherence and direct treatment cost among diabetes patients attending a tertiary healthcare facility in Ogbomosho, Nigeria. Malawi Med J, 2015; 27(2):65-70.

Fadare JO, Adeoti AO, Desalu OO, Enwere OO, Makusidi AM, Ogunleye O, Sunmonu TA, Truter I, Akunne OO, Godman B. The prescribing of generic medicines in Nigeria: knowledge, perceptions and attitudes of physicians. Expert Rev Pharmacoecon Outcomes Res, 2016; 16(5):639-50.

Fadare JO, Enwere OO, Adeoti AO, Desalu OO, Godman B. Knowledge and attitude of physicians towards the cost of commonly prescribed medicines: a case study in three Nigerian healthcare facilities. Value Health Reg Issues, 2020; 22:68-74.

Gerstein HC. Diabetes: dysglycaemia as a cause of cardiovascular outcomes. Nat Rev Endocrinol 2015;11 (9):508-10.

Gillani AH, Aziz MM, Masood I, Saqib A, Yang C, Chang J, Mohamed Ibrahim MI, Fang Y. Direct and indirect cost of diabetes care among patients with type 2 diabetes in private clinics: a multicenter study in Punjab, Pakistan. Expert Rev Pharmacoecon Outcomes Res, 2018; 18(6):647-53.

Godman B, Shrank W, Andersen M, Berg C, Bishop I, Burkhardt $\mathrm{T}$, et al. Comparing policies to enhance prescribing efficiency in Europe through increasing generic utilization: changes seen and global implications. Expert Rev Pharmacoecon Outcomes Res, 2010; 10(6):707-22.

Godman B. Health authority activities to enhance the quality and efficiency of medicine use and their impact. Adv Hum Biol, 2021a; 11:11-6.

Godman B. Biosimilars are becoming indispensable in the management of multiple diseases although concerns still exist. Bangladesh J Med Sci, 2021b; 20(1):5-10.

Godman B, Wettermark B, van Woerkom M, Fraeyman J, Alvarez-Madrazo S, Berg C, Bishop I, Bucsics A, Campbell S, Finlayson AE, Fürst J, Garuoliene K, Herholz H, Kalaba M, Laius O, Piessnegger J, Sermet C, Schwabe U, Vlahović-Palčevski VV, Markovic-Pekovic V, Vončina L, Malinowska K, Zara C, Gustafsson LL. Multiple policies to enhance prescribing efficiency for established medicines in Europe with a particular focus on demand-side measures: findings and future implications. Front Pharmacol, 2014a; 5;106.

Godman B, de Assis Acurcio F, Guerra Junior AA, AlvarezMadrazo S, Faridah Aryani MY et al. Initiatives among authorities to improve the quality and efficiency of prescribing and the implications. J Pharma Care Health Syst, 2014b; 1(3):1-15.

Godman B, Hill A, Simoens S, Kurdi A, Gulbinovič J, Martin AP. Timoney A, Gotham D, Wale J, Bochenek T, Rothe C. Pricing of oral generic cancer medicines in 25 European countries; findings and implications. Generics Biosimilars Initiative J, 2019; 8(2):49-70.

Godman B, Basu D, Pillay Y, Mwita JC, Rwegerera GM, Anand Paramadhas BD, Tiroyakgosi C, Okwen PM, Niba LL, Nonvignon J, Sefah I, Oluka M, Guantai AN, Kibuule D, Kalemeera F, Mubita M, Fadare J, Ogunleye OO, Distiller LA, Rampamba EM, Wing J, Mueller D, Alfadl A, Amu AA, Matsebula Z, Kalungia A, Zaranyika T, Masuka N, Wale J, Hill R, Kurdi A, Timoney A, Campbell S, Meyer JC. Review of ongoing activities and challenges to improve the care of patients with type 2 diabetes across Africa and the implications for the future. Front Pharmacol, 2020a; 11:108.

Godman B, Basu D, Pillay Y, Almeida P, Mwita JC, Rwegerera GM, Anand Paramadhas BD, Tiroyakgosi C, Patrick O, Niba LL, Sefah I,Oluka M, Guantai AN, Kibuule D, Kalemeera F, Mubita M, Fadare J, Ogunleye OO, Rampamba EM, Wing J, Mueller D, Alfadl A, Amu AA, Matsebula Z, Kalungia AC, Zaranyika T, Masuka N, Wale J, Hill R, Kurdi A, Timoney A, Campbell S, Meyer JC. Ongoing and planned activities to improve the management of patients with type 1 diabetes across Africa; implications for the future. Hosp Pract, 2020b; 48(2):51-67.

Godman B, Haque M, Islam S, Iqbal S, Urmi UL, Kamal ZM, Shuvo SA, Rahman A, Kamal M, Haque M, Jahan I, Islam MZ, Hossain MM, Munzur-E-Murshid, Kumar S, Charan J, Bhatt R, Dutta S, Abhayanand JP, Sharma Y, Saleem Z, Phuong TNT, Kwon HY, Kurdi A, Wale J, Sefah I. Rapid assessment of price instability and paucity of medicines and protection for COVID-19 across Asia: findings and public health implications for the future. Front Public Health, 2020c; 8(744) :585832.

Godman B, Haque M, McKimm J, Abu Bakar M, Sneddon J, Wale J, Campbell S, Martin AP, Hoxha I, Abilova V, Anand Paramadhas BD, Mpinda-Joseph P, Matome M, de Lemos LLP, Sefah I, Kurdi A, Opanga S, Jakupi A, Saleem Z, Hassali MA, Kibuule D, Fadare J, Bochenek T, Rothe C, Furst J, Markovic-Pekovic V, Bojanić L, Schellack N, Meyer JC, Matsebula Z, Phuong TNT, Thanh BN, Jan S, Kalungia A, Mtapuri-Zinyowera S, 
Sartelli M, Hill R. Ongoing strategies to improve the management of upper respiratory tract infections and reduce inappropriate antibiotic use particularly among lower and middle-income countries: findings and implications for the future. Curr Med Res Opin, 2020d; 36(2):301-27.

Godman B, McCabe H, Leong TD et al. Fixed dose drug combinations - are they pharmacoeconomically sound? Findings and implications especially for lower- and middle-income countries. Expert Rev Pharmacoecon Outcomes Res, 2020e; 20(1):1-26.

Gotham D, Barber MJ, Hill A. Production costs and potential prices for biosimilars of human insulin and insulin analogues. BMJ Global Health, 2018; 3(5):e000850.

Gouda HN, Charlson F, Sorsdahl K, Ahmadzada S, Ferrari AJ, Erskine H, Leung J, Santamauro D, Lund C, Aminde LN, Mayosi BM, Kengne AP, Harris M, Achoki T, Wiysonge CS, Stein DJ, Whiteford H. Burden of non-communicable diseases in sub-Saharan Africa, 1990-2017: results from the Global Burden of Disease Study 2017. Lancet Glob Health, 2019; 7(10):e1375-87.

Hadjiyianni I, Dahl D, Lacaya LB, Pollom RK, Chang CL, Ilag LL. Efficacy and safety of LY2963016 insulin glargine in patients with type 1 and type 2 diabetes previously treated with insulin glargine. Diabetes Obes Metab 2016; 18(4):425-9.

Hamid S, Groot W, Pavlova M. Trends in cardiovascular diseases and associated risks in sub-Saharan Africa: a review of the evidence for Ghana, Nigeria, South Africa, Sudan and Tanzania. Aging Male, 2019; 22:1-8.

Haque M, Islam S, Kamal ZM, Akter F, Jahan I, Rahim MSA, Sultana N, Alam AM, Munzur-E-Murshid, Halim-Khan MA, Deeba F, Bakar MA, Nahar S, Mozaffor M, Urmi UL,Saikat TR, Islam MZ, Haque M, Iqbal S, Hossain MM, Naher N, Allocati E, Godman B. Ongoing efforts to improve the management of patients with diabetes in Bangladesh and the implications. Hosp Pract, 2021a; 1-7.

Haque M, Abubakar A, Ogunleye O, Sani I, Sefah I, Kurdi A, Islam S, Godman B. Changes in availability, utilization, and prices of medicines and protection equipment for COVID-19 in an urban population of Northern Nigeria. J Res Pharm Pract, 2021b; 10(1):17-22.

Haque M, Kumar S, Charan J, Bhatt R, Islam S, Dutta S, Abhayanand JP, Sharma Y, Sefah I, Kurdi A, Wale J, Godman B. Utilisation, availability and price changes of medicines and protection equipment for COVID-19 in India: findings and implications short title: COVID-19 and price changes of treatments in India. Front Pharmacol, 2021c; 11(1822):582154

Hassanein M, Al-Arouj M, Hamdy O, Bebakar WMW, Jabbar A, Al-Madani A, Hanif W, Lessan N, Basit A, Tayeb K, Omar M, Abdallah K, Al Twaim A, Buyukbese MA, El-Sayed AA, Ben-Nakhi A. Diabetes and Ramadan: practical guidelines. Diabetes Res Clin Pract, 2017; 126:303-16.

Hemmingsen B, Metzendorf MI, Richter B. (Ultra-)long-acting insulin analogues for people with type 1 diabetes mellitus. Cochrane Database Syst Rev, 2021; 3:Cd013498.

India State-Level Disease Burden Initiative Diabetes Collaborators. The increasing burden of diabetes and variations among the states of India: the Global Burden of Disease Study 1990-2016. Lancet Glob Health, 2018; 6(12):e1352-62.

International Diabetes Feceration. IDF Africa Members, 2019a. Available via https://idf.org/our-network/regions-members/africa/ members/25-south-africa.html.

International Diabetes Federation. IDF Atlas Ninth Edition, 2019b. Available via https://diabetesatlas.org/upload/resources/ material/20200106 152211 IDFATLAS9e-final-web.pdf.

International Hypoglycaemia Study Group. Hypoglycaemia, cardiovascular disease, and mortality in diabetes: epidemiology, pathogenesis, and management. Lancet Diabetes Endocrinol, 2019; 7(5):385-96.

International Insulin Foundation. Fact sheet on diabetes in sub-Saharan Africa, 2006. Available via http://www.access2insulin.org/ uploads/4/9/1/0/4910107/factsheet.pdf

Jakovljevic MB, Milovanovic O. Growing burden of noncommunicable diseases in the emerging health markets: the case of BRICS. Front Public Health, 2015; 3:65.
Jensen TB, Kim SC, Jimenez-Solem E, Bartels D, Christensen HR, Andersen JT. Shift from adalimumab originator to biosimilars in Denmark. JAMA Intern Med, 2020; 180(6):902-3.

Kew J. Aspen pharmacare to deliver J\&J vaccines in next three months. 2021. Available via https://www.bloomberg.com/news/articles/202103-12/aspen-pharmacare-to-deliver-j-j-vaccines-in-next-three-months

Khan JAM, Ahmed S, Evans TG. Catastrophic healthcare expenditure and poverty related to out-of-pocket payments for healthcare in Bangladesh-an estimation of financial risk protection of universal health coverage. Health Policy Plan, 2017; 32(8):1102-10.

Kibuule D, Nambahu L, Sefah IA, Kurdi A, Phuong TNT, Kwon HY, Godman B. Activities in Namibia to limit the prevalence and mortality from COVID-19 including community pharmacy activities and the implications. Sch Acad J Pharm, 2021; 10(5):82-92.

Kivoto PM, Mulaku M, Ouma C, Ferrario A, Kurdi A, Godman B, Oluka M. Clinical and financial implications of medicine consumption patterns at a leading referral hospital in Kenya to guide future planning of care. Front Pharmacology, 2018; 9:1348.

Lamb YN, Syed YY. LY2963016 insulin glargine: a review in type 1 and 2 diabetes. BioDrugs: clinical immunotherapeutics, biopharmaceuticals and gene therapy. 2018; 32(1):91-8.

Laranjeira FO, de Andrade KRC, Figueiredo A, Silva EN, Pereira MG. Long-acting insulin analogues for type 1 diabetes: an overview of systematic reviews and meta-analysis of randomized controlled trials. PloS One, 2018; 13(4):e0194801.

Lee TY, Kuo S, Yang CY, Ou HT. Cost-effectiveness of longacting insulin analogues vs intermediate/long-acting human insulin for type 1 diabetes: a population-based cohort followed over 10 years. Br J Clin Pharmacol, 2020; 86(5):852-60.

Lin X, Xu Y, Pan X, Xu J, Ding Y, Sun X, Song X, Ren Y, Shan PF. Global, regional, and national burden and trend of diabetes in 195 countries and territories: an analysis from 1990 to 2025. Sci Rep, 2020; 10(1):14790.

Liu J, Ren Z-H, Qiang H, Wu J, Shen M, Zhang L, Lyu J. Trends in the incidence of diabetes mellitus: results from the Global Burden of Disease Study 2017 and implications for diabetes mellitus prevention. BMC Public Health, 2020; 20(1):1415.

Lontchi-Yimagou E, Mapa-Tassou C, Dehayem MY, Essi MJ, Saji J, Takogue R, Sobngwi E, Mbanya JC. The effect of free diabetes care on metabolic control and on health-related quality of life among youths with type 1 diabetes in Cameroon. BMJ Open Diabetes Res Care, 2017; 5(1):e000397.

Madela S, James S, Sewpaul R, Madela S, Reddy P. Early detection, care and control of hypertension and diabetes in South Africa: a community-based approach. Afr J Prim Health Care Fam Med, 2020; 12(1):e1-9.

Mao W, Vu H, Xie Z, Chen W, Tang S. Systematic review on irrational use of medicines in China and Vietnam. PloS One, 2015; 10(3):e0117710.

Mapa-Tassou C, Katte JC, Mba Maadjhou C, Mbanya JC Economic impact of diabetes in Africa. Curr Diab Rep, 2019; 19(2):5.

Matusewicz W, Godman B, Pedersen HB, Furst J, Gulbinovic $\mathrm{J}$, Mack A, et al. Improving the managed introduction of new medicines: sharing experiences to aid authorities across Europe. Expert Rev Pharmacoecon Outcomes Res, 2015; 15(5):755-8.

Mbanya JC, Naidoo P, Kolawole BA, Tsymbal E, McMaster A, Karamchand S, Kaplan H,Rambiritch V, Cotton M, Malek R, Allen Distiller L, Leisegang RF. Management of adult patients with type 1 diabetes mellitus in Africa: a post-hoc cohort analysis of 12 African countries participating in the International Diabetes Management Practices Study (Wave 7). Medicine (Baltimore), 2020; 99(25):e20553.

Mbui JM, Oluka MN, Guantai EM, Sinei KA, Achieng L, Baker A, Jande M, Massele A, Godman B. Prescription patterns and adequacy of blood pressure control among adult hypertensive patients in Kenya; findings and implications. Expert Rev Clin Pharmacol, 2017; 10(11):1263-71.

Meyer JC, Schellack N, Stokes J, Lancaster R, Zeeman H, Defty D, Godman B, Steel G. Ongoing initiatives to improve the quality and 
efficiency of medicine use within the public healthcare system in South Africa; a preliminary study. Front Pharmacol, 2017; 8:751.

Miljković N, Godman B, van Overbeeke E, Kovačević M, Tsiakitzis K, Apatsidou A, Nikopoulou A, Yubero CG, Portillo Horcajada L, Stemer G, Kuruc-Poje D, De Rijdt T, Bochenek T, Huys I, Miljković B. Risks in antibiotic substitution following medicine shortage: health-care failure mode and effect analysis of six European Hospitals. Front Med, $2020 ; 7: 157$.

Ministry of Health Republic of Kenya. Kenya essential medicines list - 2019, 2019. Availabe via https://www.health.go.ke/wpcontent/uploads/2020/03/Kenya-Essential-Medicines-List-2019.pdf.

Monami M, Marchionni N, Mannucci E. Long-acting insulin analogues vs. NPH human insulin in type 1 diabetes. A meta-analysis. Diabetes Obes Metab, 2009; 11(4):372-8.

Moon JC, Godman B, Petzold M, Alvarez-Madrazo S, Bennett K, Bishop I, Bucsics A, Hesse U, Martin A, Simoens S, Zara C,Malmström RE. Different initiatives across Europe to enhance losartan utilization post generics: impact and implications. Front Pharmacol, 2014; 5:219.

Moorkens E, Godman B, Huys I, Hoxha I, Malaj A, Keuerleber S, Stockinger S, Mörtenhuber S, Dimitrova M, Tachkov K, Vončina L, Palčevski VV, Achniotou G, Slabý J, Popelková L, Kohoutová K, Bartels D, Laius O, Martikainen JE, Selke GW, Kourafalos V, Magnússon E, Einarsdóttir R, Adams R, Joppi R, Allocati E, Jakupi A, Viksna A, GreičiūtèKuprijanov I, Vella Bonanno P, Suttorp V, Melien Ø, Plisko R, Mardare I, Meshkov D, Novakovic T, Fürst J, Zara C, Marković-Peković V, Grubiša N, Befrits G, Puckett R, Vulto AG. The expiry of Humira ${ }^{\circledR}$ market exclusivity and the entry of adalimumab biosimilars in Europe: an overview of pricing and national policy measures. Front Pharmacol, 2021; 11(1993):591134.

Murphy A, Palafox B, Walli-Attaei M, Powell-Jackson T, Rangarajan S, Alhabib KF, Avezum AJ, Calik KBT, Chifamba J, Choudhury T, Dagenais G, Dans AL, Gupta R, Iqbal R, Kaur M, Kelishadi R, Khatib R, Kruger IM, Kutty VR, Lear SA, Li W, Lopez-Jaramillo P, Mohan V, Mony PK, Orlandini A, Rosengren A, Rosnah I, Seron P, Teo K, Tse LA, Tsolekile L, Wang Y, Wielgosz A, Yan R, Yeates KE, Yusoff K, Zatonska K, Hanson K, Yusuf S, McKee M. The household economic burden of non-communicable diseases in 18 countries. BMJ Glob Health, 2020; 5(2):e002040.

Mutyambizi C, Pavlova M, Chola L, Hongoro C, Groot W. Cost of diabetes mellitus in Africa: a systematic review of existing literature. Global Health, 2018; 14(1):3.

Mwita JC, Francis JM, Omech B, Botsile E, Oyewo A, Mokgwathi M, Molefe-Baikai OJ, Godman B, Tshikuka JG. Glycaemic, blood pressure and low-density lipoprotein-cholesterol control among patients with diabetes mellitus in a specialised clinic in Botswana: a crosssectional study. BMJ Open, 2019; 9(7):e026807.

Ndilwa L. Reason to smile for diabetic patients in Tanzania, 2020. Available via https://www.thecitizen.co.tz/tanzania/news/reason-tosmile-for-diabetic-patients-in-tanzania-3230790

Niaz Q, Godman B, Massele A, Campbell S, Kurdi A, Kagoya HR, Kibuule D. Validity of World Health Organisation prescribing indicators in Namibia's primary healthcare: findings and implications. Int $\mathrm{J}$ Qual Health Care, 2019; 31(5):338-45.

Ogunleye OO, Basu D, Mueller D, Sneddon J, Seaton RA, Yinka-Ogunleye AF, Wamboga J, Miljković N, Mwita JC, Rwegerera GM, Massele A, Patrick O, Niba LL, Nsaikila M, Rashed WM, Hussein MA, Hegazy R, Amu AA, Boahen-Boaten BB, Matsebula Z, Gwebu P, Chirigo B, Mkhabela N, Dlamini T, Sithole S, Malaza S, Dlamini S, Afriyie D, Asare GA, Amponsah SK, Sefah I, Oluka M, Guantai AN, Opanga SA, Sarele TV, Mafisa RK, Chikowe I, Khuluza F, Kibuule D, Kalemeera F, Mubita M, Fadare J, Sibomana L, Ramokgopa GM, Whyte C, Maimela T, Hugo J, Meyer JC, Schellack N, Rampamba EM, Visser A, Alfadl A, Malik EM, Malande OO, Kalungia AC, Mwila C, Zaranyika T, Chaibva BV, Olaru ID, Masuka N, Wale J, Hwenda L, Kamoga R, Hill R, Barbui C, Bochenek T, Kurdi A, Campbell S, Martin AP, Phuong TNT, Thanh BN, Godman B. Response to the novel Corona Virus (COVID-19) pandemic across Africa: successes, challenges, and implications for the future. Front Pharmacol, $2020 ; 11: 1205$
Opanga S, Njeri LW, Kimonge D, Godman B, Oluka M. Assessing utilisation and expenditure on long-acting insulin analogues in Kenya; findings and implications for the future. Sch Acad J Pharm, 2021a; 10(4):63-70.

Opanga SA, Rizvi N, Wamaitha A, Sefah IA, Godman B. Availability of medicines in community pharmacy to manage patients with COVID-19 in Kenya; pilot study and implications. Sch Acad J Pharm. 2021b; 10(3):36-42.

Oyando R, Njoroge M, Nguhiu P, Sigilai A, Kirui F, Mbui J, Bukania Z, Obala A, Munge K, Etyang A, Barasa E. Patient costs of diabetes mellitus care in public health care facilities in Kenya. Int J Health Plann Manage, 2020; 35(1):290-308.

Pedersen-Bjergaard U, Kristensen PL, Beck-Nielsen H, Nørgaard K, Perrild H, Christiansen JS, Jensen T, Hougaard P, Parving HH, Thorsteinsson B, Tarnow L. Effect of insulin analogues on risk of severe hypoglycaemia in patients with type 1 diabetes prone to recurrent severe hypoglycaemia (HypoAna trial): a prospective, randomised, openlabel, blinded-endpoint crossover trial. Lancet Diabetes Endocrinol, 2014; 2(7):553-61.

Peyrot M, Barnett AH, Meneghini LF, Schumm-Draeger PM. Insulin adherence behaviours and barriers in the multinational global attitudes of patients and physicians in insulin therapy study. Diabet Med, 2012; 29(5):682-9.

Pillay DK, Ross AJ, Campbell L. A review of hypoglycaemia in a South African family practice setting. Afr J Prim Health Care Fam Med, 2016; 8(1):e1-6.

Premium Times. Diabetes: Novo Nordisk to offer free insulin to children in Nigeria, Ghana, 2020. Available via https://www. premiumtimesng.com/health/426147-diabetes-novo-nordisk-to-offer-freeinsulin-to-children-in-nigeria-ghana.html

Rahim FF, Abdulrahman SA, Kader Maideen SF, Rashid A. Prevalence and factors associated with prediabetes and diabetes in fishing communities in penang, Malaysia: a cross-sectional study. PLoS One, 2020; 15(2):e0228570.

Rijal A, Adhikari TB, Khan JAM, Berg-Beckhoff G. The economic impact of non-communicable diseases among households in South Asia and their coping strategy:a systematic review. PloS One, 2018; 13(11): 0205745 .

Rwegerera GM, Molefe-Baikai OJ, Masaka A, Shimwela M, Rivera YP, Oyewo TA, Godman BB, Massele A, Habte D. Prevalence of chronic kidney disease using estimated glomerular filtration rate among diabetes patients attending a tertiary clinic in Botswana. Hosp Pract (1995), 2018; 46(4):214-20.

Rys P, Wojciechowski P, Rogoz-Sitek A, Niesyczyński G, Lis J, Syta A, Malecki MT. Systematic review and meta-analysis of randomized clinical trials comparing efficacy and safety outcomes of insulin glargine with NPH insulin, premixed insulin preparations or with insulin detemir in type 2 diabetes mellitus. Acta Diabetol, 2015; 52(4):649-62.

Saeed A, Saeed H, Saleem Z, Yang C, Jiang M, Zhao M, Ji W, Aziz MM, Khan FU, Gillani AH, Atif N, Fang Y, Babar ZUD. Impact of National Drug Pricing Policy 2018 on access to medicines in Lahore division, Pakistan: a pre-post survey study using WHO/HAI methodology. BMJ open, 2020; 10(10):e034720.

Sandoz - A Novartis Division. Kenya is first country to launch 'Novartis Access', expanding affordable treatment options against chronic diseases,. 2015. Available via https://www.sandoz.com/news/mediareleases/kenya-first-country-launch-novartis-access-expanding-affordabletreatment

Schäfermann S, Neci R, Ndze EN, Nyaah F, Pondo VB, Heide L. Availability, prices and affordability of selected antibiotics and medicines against non-communicable diseases in western Cameroon and Northeast DR Congo. PloS One, 2020; 15(1):e0227515.

Sefah I, Ogunleye O, Essah D, Opanga S, Rizvi N, Wamaitha A, Guantai AN, Chikowe I, Khuluza F, Kibuule D, Nambahu L, Abubakar AR, Sani IH, Saleem Z, Kalungia AC,Thi Phuong TN, Haque M, Islam S, Kumar S, Sneddon J, Wamboga J, Wale J, Miljković N, Kurdi A, Martin AP, 
Godman B. Rapid assessment of the potential paucity and price increases for suggested medicines and protection equipment for COVID-19 across developing countries with a particular focus on Africa and the implications. Front Pharmacol, 2021; 11(2055):588106.

Semlitsch T, Engler J, Siebenhofer A, Jeitler K, Berghold A, Horvath K. (Ultra-)long-acting insulin analogues versus NPH insulin (human isophane insulin) for adults with type 2 diabetes mellitus. Cochrane Database Syst Rev, 2020; 11:Cd005613.

Shafie AA, Ng CH. Cost-effectiveness of insulin glargine and insulin detemir in the basal regimen for naïve insulin patients with type 2 diabetes mellitus (T2DM) in Malaysia. Clinicoecon Outcomes Res, 2020; 12:333-43.

Shannon GD, Haghparast-Bidgoli H, Chelagat W, Kibachio J, Skordis-Worrall J. Innovating to increase access to diabetes care in Kenya: an evaluation of Novo Nordisk's base of the pyramid project. Glob Health Action, 2019; 12(1):1605704.

Singh S. Biocon's Malaysia Insulin Glargine manufacturing facility receives EU GMP certification. 2019. Available via https:// indiamedtoday.com/biocons-malaysia-insulin-glargine-manufacturingfacility-receives-eu-gmp-certification/

Soleymani F, Godman B, Yarimanesh P, Kebriaeezade A. Prescribing patterns of physicians working in both the direct and indirect treatment sectors in Iran; findings and implications. J Pharm Health Serv Res, 2019; 10:407-13.

Spain CV, Wright JJ, Hahn RM, Wivel A, Martin AA. Selfreported barriers to adherence and persistence to treatment with injectable medications for type 2 diabetes. Clin Ther, 2016; 38(7):1653-64.e1.

Tricco AC, Ashoor HM, Antony J, Bouck Z, Rodrigues M, Pham B, Khan PA, Nincic V, Darvesh N, Yazdi F, Ghassemi M, Ivory JD, Veroniki
AA, Yu CH, Moja L, Straus SE. Comparative efficacy and safety of ultralong-acting, long-acting, intermediate-acting, and biosimilar insulins for type 1 diabetes mellitus: a systematic review and network meta-analysis. J Gen Intern Med, 2021.

Venkataraman AP, Laxminarayana K, Samhita S. Knowledge, attitude and practice of insulin use of diabetic patients in India. Pharmacol Clin Pharm Res, 2020; 5(1):23-32.

WHO. WHO launches first-ever insulin prequalification programme to expand access to life-saving treatment for diabetes, 2019 Available via https://www.who.int/news/item/13-11-2019-who-launchesfirst-ever-insulin-prequalification-programme-to-expand-access-to-lifesaving-treatment-for-diabetes

Zeng W, Finlayson AE, Shankar S, de Bruyn W, Godman B. Prescribing efficiency of proton pump inhibitors in China: influence and future directions. BMC Health Serv Res, 2015; 15:11.

How to cite this article:

Haque M, Islam S, Abubakar AR, Sani IH, Opanga S, Kamal ZM, Akter F, Godman B. Utilization and expenditure on long-acting insulin analogs among selected middle-income countries with high patient co-payment levels: findings and implications for the future. J Appl Pharm Sci, 2021; 11(07):172-182. 